\title{
Pengaruh Model Pembelajaran dan Gaya Berpikir Terhadap Hasil Belajar Mata Kuliah Filsafat Pendidikan
}

\author{
Hamlan Andi Basso Malla ${ }^{1}$ \\ Herlina $^{2}$ \\ Misnah $^{3}$
}

\begin{abstract}
This study aims at revealling the effect of instructional models and students thinking styles on the students learning outcomes of the educational philosophy course at the IAIN Palu. The research method used in this research was quasi experiment with a $2 \times 2$ factorial design, data were analyzed statistically using ANAVA. The result of research shows that 1) the students learning outcomes who learned through deep learning model is higher than the students who learned through surface learning; 2) there is an interaction effect between instructional model with thinking style on the learning outcomes of educational philosophy course; 3) student learning outcomes using deep learning model and have divergent thinking style is higher than student learning outcomes that have convergent thinking style; 4) student learning outcomes using surface learning model and have the convergent thinking style is higher than student learning outcomes that have divergent thinking style.
\end{abstract}

Keywords: deep learning, surface learning, diverging, convergent, Philosophy of Education.

\begin{abstract}
Abstrak: Penelitian ini bertujuan untuk mengungkap pengaruh strategi pembelajaran dan gaya berpikir mahasiswa terhadap hasil belajar mata kuliah Filsafat Pendidikan di IAIN Palu. Metode penelitian yang digunakan adalah quasi eksperimen dengan desain faktorial $2 \times 2$, data dianalisis secara statistik menggunakan ANAVA. Hasil penelitian menunjukkan bahwa 1) hasil belajar mahasiswa yang belajar menggunakan model deep learning lebih tinggi dari pada mahasiswa yang belajar menggunakan surface learning; 2) terdapat pengaruh interaksi antara model pembelajaran dengan gaya berpikir terhadap hasil belajar filsafat pendidikan; 3) hasil belajar mahasiswa yang menggunakan model deep learning dan memiliki gaya berpikir divergen lebih tinggi dari hasil belajar mahasiswa yang memiliki gaya berpikir konvergen; 4) hasil belajar mahasiswa yang menggunakan model surface learning dan memiliki gaya berpikir konvergen lebih tinggi dari hasil belajar mahasiswa yang memiliki gaya berpikir divergen.
\end{abstract}

Kata kunci: deep learning, surface learning, divergen, konvergen, filsafat pendidikan.

\section{PENDAHULUAN}

Di tengah era globalisasi dan persaingan ketat pada berbagai dimensi kehidupan seperti saat ini, setiap individu harus dapat menyesuaikan diri dengan setiap perkembangan yang terjadi. Tingginya permintaan untuk terus berkembang menyebabkan kemunculan berbagai keterampilan baru dalam setiap aspek kehidupan.
Kondisi ini tidak hanya terjadi pada komponen kemampuan manusia pada aspek keterampilan, tetapi juga pada aspek pengetahuan. Kemunculan displin ilmu-ilmu baru sejalan dengan munculnya berbagai masalah dan fenomena yang terjadi pada kehidupan manusia, menjadi hal yang sudah lumrah. Meski cabang ilmu dan disiplin ilmu

\footnotetext{
${ }^{1}$ Hamlan Andi Basso Malla, Fakultas Tarbiyah, IAIN Palu, email: dr.hamlan@yahoo.co.id, phone: 085256696169

${ }^{2}$ Herlina, Program Studi PGSD, FKIP, Universitas Tadulako, email: herlina@untad.acd.id

${ }^{3}$ Misnah, Program Studi Pendidikan Sejarah, FKIP, Universitas Tadulako, email: 
baru terus saja bermunculan, namun bukan berarti cabang ilmu-ilmu sebelumnya menjadi hilang dan tergantikan.

Filsafat adalah merupakan induk ilmu pengetahuan, berfilsafat artinya berpikir mendalam tentang hakikat segala sesuatu. Kristiawan $(2016 ; 1)$ menyatakan bahwa filsafat merupakan kata serapan dari bahasa arab falsafah yang juga berasal dari bahasa yunani, philosophia yang berarti philos = cinta, suka (loving), dan sophia $=$ pengetahuan, hikmah (wisdom). Jadi philosophia berarti cinta kepada kebijaksanaan atau cinta kepada kebenaran. Ditinaju dari segi praktisnya filsafat berarti 'alam pikiran' atau 'alam berpikir'. Berfilsafat artinya berpikir, olah pikir. Meskipun berfilsafat adalah berpikir, namun tidak semua berpikir masuk pada praksis berfilsafat. Berfilsafat adalah berpikir secara mendalam dan sungguh-sungguh untuk mencari hakikat atau kebenaran dari sesuatu. Setiap orang berfilsafat, tetapi tingkatan dan level filsafat yang dimiliki setiap orang berbedabeda bergantung kapasitas, dan pengalaman masing-masing.

Sesungguhnya terdapat hubungan yang erat antara filsafat dan ilmu pengetahuan Dewey (1985; 331) menyatakan bahwa

Rather, as he asserts mysteriously the most penetrating definition of philosophy which can be given is, then, that it is the theory of education in its most general phases.

Menurut Dewey bahwa secara misterius definisi filsafat yang paling tajam pada akhirnya adalah teori pendidikan dalam fase-fase yang paling umum. Pada kesempatan berikutnya Dewey mengemukakan bahwa Philosophy might be defined as the general theory of education
(Dewey 1985; 328). Dewey kembali menegaskan bahwa filsafat mungkin dapat didefinisikan sebagai teori pendidikan umum. Pandangan Dewey ini memberi penguatan bahwa filsafat tidak bisa terlepas dari tahapan dan proses pendidikan. Apabila dikaitkan dengan hakikat keberadaan manusia sebagai makhluk budaya yang senantiasa berpikir untuk terus mengembangkan diri, maka pandangan Dewey memberikan arah yang jelas bagi upaya berfilsafat manusia.

Filsafat Pendidikan adalah salah satu cabang dari filsafat yang sering kali ditemukan pada institusi yang menyelenggarakan Pendidikan bagi calon guru. Apabila merujuk pada pengertian filsafat seperti telah dikemukakan sebelumnya, maka secara substansi filsafat pendidikan mengajak mahasiswa untuk memikirkan secara mendalam tentang pendidikan. Sebagaimana pengertian filsafat pendidikan yang dikemukakan oleh John Dewey (Jalaluddin dan Abdullah; 2002) bahwa filsafat pendidikan merupakan suatu pembentukan kemampuan dasar yang fundamental, baik yang menyangkut daya pikir (intelektual) maupun daya perasaan (emosional), menuju ke arah tabi'at manusia. Pendapat lain dikemukakan oleh Siegel (2010;3) yang menyatakan bahwa

philosophy of education is that branch of philosophy that address philosophical questions concerning the nature, aims, and problem of education.

Mudyaharjo (2004; 3) menyatakan bahwa filsafat pendidikan adalah pengetahuan yang menyelidiki substansi pelaksanaan pendidikan yang berkaitan dengan tujuan, latar belakang, cara, hasil, dan hakikat ilmu pendidikan yang 
berhubungan dengan analisis kritis terhadap struktur dan kegunaannya. Menurut pandangan Mudyaharjo bahwa filsafat pendidikan adalah segala pengetahuan yang berhubungan dengan pendidikan, baik berkaitan dengan hakikat, latar belakang, tujuan, proses bahkan hasil serta analisis dan evaluasi terhadap struktur, kegunaan dan proses pendidikan itu sendiri. Semua hal tentang Pendidikan adalah filsafat pendidikan. Sejalan dengan pendapat Mudyaharjo, Jordan (2008) menyatakan bahwa "The philosophy of education can be defined as the study of the purposes, processes, nature and ideals of education." Filsafat pendidikan menurut Jordan dapat didefinisikan sebagai studi tentang tujuan, proses, sifat dan cita-cita pendidikan. Pandangan tentang filsafat pendidikan dikemukakan pula oleh Moore $(2010 ; 1)$ melalui pernyataan bahwa "Philosophy of education is connected with general philosophy partly by its purposes but more directly by its methods." Menurut Moore filsafat pendidikan sangat terhubung dengan filsafat secara umum, tetapi lebih fokus mengkaji tentang metode-metodenya. Oleh karena itu filsafat pendidikan tidak hanya mendasarkan kajiannya pada teori-teori dasar dan interpretasi teoritis dari dunia pendidikan, tetapi lebih diarahkan ke implementasi, sebagaimana dikemukakan oleh Bim-bad dan Egorova (2016) bahwa "Thus, within philosophy of education practice is a means of cognition, transformation, mastery of reality in the process of educational activity." Filsafat pendidikn dengan paradigma barunya menjadi praktik pendidikan sebagai sarana kognisi, transformasi, penguasaan realitas dalam proses kegiatan pendidikan.
Sementara itu Salahudin (2011; 22) merumuskan beberapa pengertian filsafat pendidikan yakni; 1) Filsafat pendidikan adalah pengetahuan yang memikirkan hakikat pendidikan secara komprehensif dan kontemplatif tentang sumber, seluk beluk pendidikan, fungsi, dan tujuan Pendidikan; 2) Filsafat pendidikan adalah pengetahuan yang mengkaji proses pendidikan dan teori-teori Pendidikan; 3) Filsafat pendidikan mengkaji hakikat guru dan anak didik dalam proses pembelajaran di kelas dan di luar kelas; 4) Filsafat pendidikan mengkaji berbagai teori kependidikan, metode, dan pendekatan daam pendidikan; 5) Filsafat pendidikan mengkaji strategi pembelajaran alternatif.; 6) Filsafat pendidikan mengkaji hakikat tentang kurikulum pendidikan; 7) Filsafat pendidikan mengkaji hakikat evaluasi pendidikan dan evaluasi pembelajaran; 8) Filsafat pendidikan mengkaji hakikat alat-alat dan media pembelajaran.

Dengan demikian ditinjau dari sisi praksisnya, filsafat pendidikan adalah mata kuliah yang mengkaji pendidikan secara menyeluruh dan komprehensif, menganalisis secara mendalam dan detail tentang hakikat, tujuan, proses, dan hasil pendidikan, bahkan melakukan kajian dan evaluasi terhadap pendidikan terhadap semua aspeknya.

Sebagai suatu kegiatan olah pikir yang logis, maka filsafat pendidikan tidak bisa melepaskan diri unsur-unsur ilmiah suatu ilmu. Unsur ontologis filsafat pendidikan berkaitan dengan keberadaan dan eksistensi filsafat dalam mengkaji pendidikan secara mendalam dan tajam. Oleh karena itu ontologis filsafat pendidikan adalah; 1) metodis yang artinya 
mengkaji dengan cara ilmiah; 2) sistematis atau teratur dan saling berhubungan; 3) koheren atau bertautan dan uraiannya tidak bertentangan; 4) rasional atau sesuai kaidah berpikir yang benar (logis); 5) komprehensif melihat objek secara keseluruhan tidak hanya dari satu sisi; 6) radikal mengurai persoalan pendidikan sampai ke akar persoalan, atau esensinya; 7) universal dalam hal kebenarannya bisa berlaku di mana saja.

Ditinjau dari sisi epistomologisnya, bahwa kebenaran penggalian dan pengetahuan filsafat ilmu harusnya bersumber dari dua komponen yakni; 1) rasionalisme di mana akal atau rasio adalah penentu dalam menentukan hasil, keputusan atau kebijakan, dan 2) empirisme di mana kebenaran kajian yang dilakukan terletak pada realitas atau pengalaman empiris yang bisa dirasakan oleh indera manusia. Aspek aksiologis filsafat Pendidikan yang merupakan nilai kegunaan dan kemanfataan berdiri di atas dua komponen yakni; etika yang berhubungan dengan moral dan estetika yang berhubungan dengan keindahan.

Penelitian ini pada dasarnya adalah membandingkan hasil belajar mata kuliah filsafat pendidikan pada mahasiswa semester 3 tahun ajaran 2017/2018, yang diberi perlakuan dengan model pembelajaran deep learning dan surface learning dengan mempertimbangkan gaya kognitif. Hasil belajar menurut Slavin $(2011 ; 255)$ adalah "hasil belajar (behavioral objectives) adalah pernyataan tentang kemampuan atau konsep yang diharapkan akan dikuasai mahasiswa pada akhir jangka waktu pembelajaran." Masih tentang hasil belajar, Aronson dan Briggs dalam Reigeluth (1983;98) menjelaskan bahwa "hasil belajar adalah kinerja yang dapat diamati yang menunjukkan bahwa kemampuan tertentu telah diakuisisi oleh peserta didik." maka Gredler $(2011 ; 117)$ menyatakan bahwa "untuk merefresentasikan hasil belajar harus memenuhi lima kapabilitas belajar," Kelima kapabilitas belajar yang dikemukakan oleh Gredler ini kemudian diperjelas oleh Gagne (2005;27-28) sebagai “intellectual skill, verbal information, cognitive strategies, motor skills, and attitudes." Kelima kapabilitas refresentasi hasil belajar tersebut dijelaskan lebih lanjut. Dengan demikian hasil belajar adalah suatu gejala yang bias diukur dan muncul pada diri peserta didik (dalam penelitian ini mahasiswa), setelah mengikuti pembelajaran.

Secara konseptual hasil belajar Filsafat Pendidikan adalah tingkat penguasaan siswa pada konsep-konsep dan teori dalam materi mata kuliah filsafat pendidikan. Hasil belajar dalam penelitian ini dibatasi pada perubahan ranah kognitif yang mencakup pengetahuan, pemahaman, penerapan dan analisis sebagai hasil dari proses pembelajaran filsafat pendidikan selama kurun waktu penelitian berdasarkan tujuan pembelajaran yang ditetapkan. Sementara secara operasional, hasil belajar filsafat pendidikan adalah skor yang diperoleh mahasiswa semester 3 tahun ajaran 2017/2018 dalam menjawab butir-butir soal yang diberikan untuk mengukur kemampuan kognitif terhadap komponen ontologies, epistomologis dan aksiologis dari filsafat pendidikan.

Merujuk pada uraian tersebut di atas, maka untuk mencapai ketercapaian kompetensi pada mata kuliah filsafat pendidikan, maka mahasiswa dituntut untuk menerapkan pendekatan dan model pembelajaran yang bisa memaksimalisasi 
kemampuan berpikir dan berfilsafat secara komprehensif. Mahasiswa juga dituntut untuk menerapkan cara-cara mengkaji, mencari, menemukan dan mengevaluasi pendidikan dengan landasan ontologis, epistomologis dan aksiologis filsafat Pendidikan itu sendiri.

Sejalan dengan hal tersebut maka dalam penelitian digunakan model pembelajaran deep learning dan surface learning learning sebagai variabel perlakuan. Model pembelajaran deep learning adalah model pembelajaran yang menuntut mahasiswa untuk berpikir kritis dan mendalam sebagaimana dikemukakan oleh Houghton (2004) yang merupakan kompilasi pendapat dari Biggs (1999) Entwistle (1988), Ramsden (1992). Dalam bukunya Houghton menyatakan bahwa definisi dari deep learning adalah examining new facts and ideas critically, and tying them into existing cognitive structures and making numerous links between ideas.

Model pembelajaran deep learning menitik beratkan kegiatan belajar pada proses memeriksa fakta dan ide baru secara kritis, dan mengikat mereka ke dalam struktur kognitif yang ada dan membuat banyak tautan antar ide.

Pandangan di atas sejalan dengan pendapat Fieldman dalam Jensen (2008) bahwa deeper learning required use to follow multiple rules of operation to complete the task. Bahwa apabila mahasiswa ingin menyelesaikan tugas yang sesuai dengan aturan dan prosedur yang standar maka sebaiknya menggunakan model pembelajaran deep learning. Lebih lanjut Jensen mengemukakan bahwa:

one must know one microlearning and than add it to other microlearning to make a complete, complex package. In other words, there are multiple thinking steps to achieving deeper learning with content.

Deep learning penting untuk menghubungkan microlearning yang satu ke microlearning lainnya untuk membuat paket yang rumit dan lengkap. Terdapat beberapa langkah berpikir untuk mencapai deep learning yang akan membantu mahasiswa dalam memahami konten secara efektif. Deep learning adalah langkah berpikir yang dinamis, pandangan ini ditegaskan oleh Pujo Soekarno dalam Suryana (2018) bahwa model pembelajaran deep learning bersifat dinamik, dimana keterkaitan antar pengetahuan digunakan sepenuhnya untuk menunjang pemahaman. Suryana lebih jauh menjelaskan bahwa pada model ini mahasiswa diajak untuk mengenal, memahami dan menerapkan pengetahuannya dalam menyelesaikan masalah dari sudut penyelesaian yang umum. Dalam hal ini tumbuhnya pemahaman terhadap terhadap materi kuliah dimungkinkan melalui penggunaan konsep dan metode dalam konteks yang berbedabeda.

Deep learning adalah model pembelajaran yang berkaitan dengan pemrosesan informasi dalam otak mahasiswa yang kompleks dan lengkap sebagaimana dikemukakan oleh Condrath (2016) bahwa terdapat 2 aspek kunci sebagai definisi model deep learning yakni

models consisting of multiple layers or stages of nonlinear information processing and methods for supervised or unsupervised learning of feature representation at successively higher, more abstract layers.

Bahwa deep learning adalah model yang terdiri dari beberapa lapisan atau tahapan pemrosesan informasi nonlinier dan metode 
pembelajaran yang diawasi atau tidak diawasi dari representasi fitur di berturut-turut lebih tinggi, lapisan yang lebih abstrak.

Jensen (2008) menyatakan terdapat 7 strategi deep learning dan menyebutnya sebagai The Deep Learning Cycle (DELC). Tujuh strategi yang dimaksud oleh Jensen adalah

1) planning the standar and curriculum;2) pre-assesing; 3) building a positive learning culture; 4); priming and activating prior knowledge; 5) acquiring new knowledge; 6) prcessing the learning deeper; 7) evaluating student learning. yaitu

Berdasarkan pendapat tersebut deep learning adalah model pembelajaran yang berorientasi pada maksimalisasi berpikir mahasiswa, di mana mahasiswa akan mengeksplorasi kemampuan berpikirnya secara maksimal sesuai langkah dan tahapan pembelajaran dalam model deep learning.

Model pembelajaran surface learning adalah model pembelajaran yang bertumpu pada motivasi belajar yang berasal dari luar diri atau motivasi ekstrinsik. Model pembelajaran ini menjadikan mahasiswa cenderung belajar karena ingin lulus saja, bukan ingin memahami atau menguasai informasi, pengetahuan, keterampilan atau sikap yang ada dalam mata kuliah. Mahasiswa yang memiliki keinginan untuk lulus tapi tidak mau kerja keras adalah kelompok mahasiswa yang bergabung dalam model pembelajaran ini.

$$
\text { Dalam tulisannya Briggs }
$$

menyatakan bahwa surface learning adalah

studying without reflecting on either purpose or strategy, treating the course as unrelated bits of knowledge, memorising facts and procedures routinely, finding difficulty in making sense of new ideas presented, feeling undue pressure and worry about work.

Mahasiswa dengan model pembelajaran surface learning cenderung mempelajari tanpa merefleksikan tujuan atau strategi, memperlakukan proses belajar sebagai bagian dari pengetahuan yang tidak terkait, menghafal fakta dan prosedur secara rutin. Selain itu dalam belajar mahasiswa sering menemukan kesulitan dalam memahami ide-ide baru yang disajikan dan merasa tekanan yang pada dasarnya tidak perlu serta selalu khawatir tentang pekerjaan. Surface learning membuat mahasiswa belajar dengan santai, lebih berorientasi untuk menghapal pengetahuan dan kurang tertarik untuk memiliki pengetahuan yang mendalam terhadap materi kuliah.

Menurut Houghton (2004) bahwa surface learning adalah Accepting new facts and ideas uncritically and attempting to store them as isolated, unconnected, items. Model surface learning cenderung menerima fakta dan ide baru secara langsung atau apa adanya, mahasiswa menjadi tidak kritis dan mencoba menyimpannya sebagai barang yang terisolasi dan tidak berhubungan dengan hal lainnya.

Sementara itu menurut Biggs dan Tang (Howei dan Bagnall; 2015) bahwa

a surface approach to learning is defined by Biggs as an approach whereby a student learns only enough to just pass assessment and fulfil the minimum requirements of a tertiary learning programme.

Dapat dimaknai bahwa pendekatan surface learning didefinisikan oleh Biggs sebagai pendekatan di mana seorang siswa hanya cukup belajar untuk lulus dari penilaian dan memenuhi persyaratan minimum dari program belajar yang 
dianggap tidak terlalu penting. Dengan demikian dapat dikatakan bahwa surface learning adalah model pembelajaran konvensional yang tidak menuntut adanya ide, gagasan dan kreatifitas mahasiswa. Kompetensi belajar diukur dari kemampuan menghapal dan kekuatan memori untuk mengingat, tanpa ada kritikan maupun analisis lebih mendalam. Surface learning mengindikasikan bahwa mahasiswa belajar hanya untuk lulus dan bukan belajar untuk memahami.

Ketercapaian kompetensi belajar pada siswa dipengaruhi oleh gaya belajar siswa dan metode pembelajaran. Gaya belajar sering juga disebut sebagai gaya kognitif, tidak ada ditemukan pembahasan yang membedakan gaya berpikir dan gaya kognitif. Sehubungan dengan hal tersebut, Stenberg (2009) menyatakan bahwa gaya kognitif secara spesifik merupakan karakteristik individu dalam menerima dan mengorganisasi. Sementara itu Uto (1994) menyatakan bahwa

Cognitive styles represent dimensions of individual differences in cognitive sphere, where individual remains relatively on a constant position. Those dimensions characterize individual's variations in a mental activity form. Hence, they are in principle contextually independent of that activity.

Menurut pendapat ini bahwa gaya kognitif Gaya kognitif merepresentasikan dimensi perbedaan individu dalam lingkup kognitif, yang cenderung menetap. Merupakan variasi karateristik individu dalam aktivitas mental, namun secara kontekstual individu tida tergantung pada aktivitas tersebut.

Pandangan serupa dikemukakan oleh Lusiana sebagaimana dikutip oleh Dwirahayu \&
Firdausi (2016) yang mendefinisikan gaya berpikir sebagai kecenderungan seseorang yang relatif tetap dalam mengatur atau memproses suatu informasi, baik dalam menerima dan memunculkan kembali informasi, ataupun memecahkan masalah. Dwirahayu \& Firdausi (2016) juga mengutip pandangan Uno yang menyatakan bahwa gaya berpikir merupakan cara yang khas dalam belajar, baik yang berkaitan dengan cara penerimaan dan pengolahan informasi, sikap terhadap informasi, maupun kebiasaan yang berhubungan dengan lingkungan belajar.

Gaya berpikir yang diajukan dalam penelitian ini adalah divergen dan konvergen, this dimension of the intellect was proposed by Guilford (Pencheva \& Papazova; 2006). Lebih lanjut keduanya mengutip theory Hudson yang menyatakan bahwa

the dimension reflects a type of thinking and associated strategies for problem solving. The learner will typically attack a problem or task by 'thinking' in a way, which is either open-ended and exploratory, or closeended and highly focused.

Dimensi divergen dan konvergen mencerminkan jenis berpikir dan menghubungkan strategi pemecahan terhadap suatu masalah. Dalam hal ini mahasiswa seringkali menghadapi problem dan tugas dengan salah satu cara berikut, yakni cara berpikir yang terbuka dan eksploratif, atau gaya berpikir tertutup dan fokus hanya pada satu persoalan.

Sebagai pelopor teori tentang gaya berpikir divergen dan konvergen Guilford (Bedget; 1981) memberikan batasan tentang kedua gaya berpikir ini dengan menyatakan bahwa gaya berpikir divergen adalah 
kemampuan memberikan beragam respon untuk satu permasalahan yang diberikan, sementara berpikir konvergen adalah kemampuan memproduksi satu jawaban benar. Batasan tentang gaya berpikir divergen dan konvergen juga dikemukakan oleh Seifert (1983:205), bahwa gaya berpikir konvergen mendorong mahasiswa untuk menyelesaikan berbagai situasi dan masalah dengan solusi yang parsial, sebaliknya gaya berpikir divergen mendorong siswa untuk menyelesaikan suatu problem atau masalah dengan solusi yang sama. Dengan demikian gaya berpikir divergen lebih bersifat terbuka dan dinamis sedangkan gaya belajar konvergen lebih cenderung tertutup dan statis. Berpikir divergen dapat menyelesaikan banyak masalah dengan banyak solusi tapi konvergen bisa menyelesaikan masalah dengan sangat baik dan hati-hati tapi tuntas.

Dalam penelitian ini belum dilakukan oleh peneliti terdahulu yang mengkaji tentang model pembelajaran deep learning pada mata kuliah filsafat pendidikan. Fokus kajian ini adalah model pembelajaran deep learning yang diimplementasikan pada mata kuliah filsafat pendidikan bagi mahasiswa semester tiga pada Fakultas Tarbiyah dan Ilmu Keguruan Institut Agama Islam Negeri Palu. Penelitian ini membandingkan antara model pembelajaran deep learning dengan model pembelajaran surface learning dengan mempertimbangkan gaya berpikir mahasiswa.

Model pembelajaran deep learning dalam praktiknya selama ini cenderung atau dominan digunakan dalam pembelajaran disiplin ilmu eksakta khususnya dalam bidang ilmu computer. Teori-teori tentang model pembelajaran deep learning sebagaimana dikemukakan oleh Biggs, Enwistle, Ramsden, Fieldman dan Jensen di atas disintesiskan bahwa model pembelajaran deep learning tidak dibatasi pada disiplin ilmu eksakta saja, akan tetapi bisa diimplementasikan pada semua disiplin ilmu. Berdasarkan penelurusan terhadap hasil hasil riset yang telah dilakukan oleh peneliti terdahulu diketahui bahwa persentase penerapan model pembelajaran deep learning pada disiplin ilmu sosial masih sangat kurang. Dalam konteks ini, penelitian ini dilakukan dalam rangka membuktikan pengaruh model pembelajaran deep learning terhadap hasil belajar mata kuliah filsafat pendidikan sebagai salah disiplin ilmu sosial dengan memperhitungkan gaya berpikir divergen dan konvergen bagi mahasiwa.

Penelitian ini mengajukan uji hipotesis bahwa hasil belajar filsafat pendidikan pada mahasiswa yang menggunakan model pembelajaran deep learning lebih tinggi dari pada hasil belajar mahasiswa yang menggunakan model pembelajaran surface learning. Penelitian ini juga membuktikan bahwa gaya berpikir divergen dapat menguatkan model pembelajaran deep learning.

Permasalahan penelitian adalah sebagai berikut; 1) apakah terdapat perbedaan hasil belajar Filsafat Pendidikan antara mahasiswa yang menggunakan model pembelajaran deep learning dengan mahasiswa yang menggunakan surface learning?; 2) Apakah terdapat perbedaan hasil belajar Filsafat Pendidikan antara mahasiswa yang memiliki gaya berpikir divergen dan mahasiswa yang memiliki gaya berpikir konvergen?; 3) apakah terdapat pengaruh interaksi antara model pembelajaran dan gaya 
berpikir terhadap hasil belajar Filsafat Pendidikan?; 4) apakah terdapat perbedaan hasil belajar antara mahasiswa yang menggunakan model pembelajaran deep learning dengan mahasiswa yang menggunakan model pembelajaran surface learning pada mahasiswa yang memiliki gaya berpikir divergen?; 5) apakah terdapat perbedaan hasil belajar antara mahasiswa yang menggunakan model pembelajaran deep learning dengan mahasiswa yang menggunakan model pembelajaran surface learning pada mahasiswa yang memiliki gaya berpikir konvergen?; 6) apakah terdapat perbedaan hasil belajar antara mahasiswa yang memiliki gaya berpikir divergen dengan mahasiswa yang memiliki gaya berpikir konvergen yang menggunakan model pembelajaran deep learning?; 7) apakah terdapat perbedaan hasil belajar antara mahasiswa yang memiliki gaya berpikir divergen dengan mahasiswa yang memiliki gaya berpikir konvergen yang menggunakan model pembelajaran surface learning?

\section{METODE PENELITIAN}

Penelitian ini menggunakan metode quasi eksperimen dengan desain factorial $2 \times 2$. Manipulasi atau perlakuan terhadap subjek penelitian ada dua yakni model pembelajaran deep learning dan model pembelajaran surface learning. Rancangan penelitian sebagai berikut:

Tabel 1. Desain penelitian Treatment by Level

\begin{tabular}{|c|c|c|}
\hline \multirow{2}{*}{$\begin{array}{l}\text { Gaya Berpikir } \\
\text { (B) }\end{array}$} & \multicolumn{2}{|c|}{ Model Pembelajaran } \\
\hline & $\begin{array}{c}\text { Deep Learning } \\
\left(\mathrm{A}_{1}\right)\end{array}$ & $\begin{array}{c}\text { Surface } \\
\text { Learning }\left(\mathrm{B}_{1}\right) \\
\end{array}$ \\
\hline Divergen $\left(\mathrm{B}_{1}\right)$ & $\mathrm{A}_{1} \mathrm{~B}_{1}$ & $\mathrm{~A}_{1} \mathrm{~B}_{1}$ \\
\hline Konvergen $\left(\mathrm{B}_{2}\right)$ & $\mathrm{A}_{1} \mathrm{~B}_{1}$ & $\mathrm{~A}_{1} \mathrm{~B}_{1}$ \\
\hline
\end{tabular}

Variabel penelitian terdiri atas:

variabel terikat adalah hasil belajar Mata Kuliah Filsafat Pendidikan; (2) variabel bebas atau variabel perlakuan $\mathrm{A}_{1}$ model pembelajaran deep learning dan $\mathrm{A}_{2}$ model pembelajaran surface learning; (3) variabel atribut adalah $\mathrm{B}_{1}$ gaya berpikir divergen dan $\mathrm{B}_{2}$ gaya berpikir konvergen.

Seluruh mahasiswa Pendidikan Agama Islam Fakultas Tarbiyah IAIN Palu menjadi populasi target, sedangkan sampel penelitian diambil dari mahasiswa semester 3 melalui teknik simple random sampling. Terdapat 3 kelas yang memprogramkan mata kuliah Filsafat Pendidikan. Secara random kelas B dan C terpilih dan kelas B dijadikan sebagai kelas eksperimen (model pembelajaran deep learning) dan kelas C menjadi kelas kontrol (surface learning). Jumlah mahasiswa dari kedua kelas tersebut adalah 84. 42 dari kelas B dan 42 dari kelas C. Untuk membedakan gaya berpikir divergen dan konvergen, semua siswa diberikan test baku yang dikembangkan oleh Guilford. Test berhasil menempatkan diperoleh 11 orang (42 x $27 \%$ ) kelompok atas dengan gaya berpikir divergen dan 11 (42 x 27\%) kelompok bawah dengan gaya berpikir konvergen.

Tabel 2. Komposisi Sampel Penelitian

\begin{tabular}{llll}
\hline $\begin{array}{r}\text { Model } \\
\text { Membelajaran } \\
(\mathrm{A})\end{array}$ & $\begin{array}{c}\text { Deep } \\
\text { Learning } \\
\left(\mathrm{A}_{1}\right)\end{array}$ & $\begin{array}{c}\text { Surface } \\
\text { Learning } \\
\left(\mathrm{A}_{2}\right)\end{array}$ & Jumlah \\
$\begin{array}{l}\text { Gaya } \\
\text { Berpikir } \\
(\mathrm{B})\end{array}$ & 11 & 11 & 22 \\
\hline Divergen $\left(\mathrm{B}_{1}\right)$ & 11 & 11 & 22 \\
Konvergen $\left(\mathrm{B}_{2}\right)$ & 11 & 22 & 44 \\
$\quad$ Jumlah & 22 & 22 & \\
\hline
\end{tabular}


Keterangan:

$\mathrm{A}_{1} \mathrm{~B}_{1}=$ kelompok mahasiswa yang menggunakan model pembelajaran deep learning dan memiliki gaya berpikir divergen

$\mathrm{A}_{1} \mathrm{~B}_{2}=$ kelompok mahasiswa yang menggunakan model pembelajaran deep learning dan memiliki gaya berpikir konvergen

$\mathrm{A}_{2} \mathrm{~B} 1$ = kelompok mahasiswa yang menggunakan model pembelajaran surface learning dan memiliki gaya berpikir divergen

$\mathrm{A}_{2} \mathrm{~B}_{2}=$ kelompok mahasiswa yang menggunkana model pembelajaran surface learning dan memiliki gaya berpikir konvergen

Uji hipotesis dilakukan dengan analisis varian (ANAVA) dua jalur setelah dilakukan uji normalitas menggunakan uji Liliefors (Sudjana, 2005).

\section{HASIL DAN PEMBAHASAN}

\section{Hasil Penelitian}

Hasil penelitian yang ditampilkan adalah data statistik hasil belajar mahasiswa pada mata kuliah filsafat pendidikan. Data ini di ambil dengan memberikan tes tulis berbentuk soal pilihan ganda. Paparan data statistik hasil penelitian adalah sebagai berikut:

Tabel 3. Data Hasil Penelitian

\begin{tabular}{|c|c|c|c|c|}
\hline \multirow{2}{*}{\multicolumn{2}{|c|}{ Gaya Berpikir }} & \multicolumn{3}{|c|}{ Model Pembelajaran } \\
\hline & & \multirow{2}{*}{$\begin{array}{c}\begin{array}{c}\text { Deep } \\
\text { Learning } \\
\left(\mathbf{A}_{1}\right)\end{array} \\
11\end{array}$} & \multirow{2}{*}{$\begin{array}{c}\begin{array}{c}\text { Surface } \\
\text { Learning } \\
\left(\mathbf{A}_{2}\right)\end{array} \\
11\end{array}$} & \multirow{2}{*}{$\begin{array}{l}\mathbf{\Sigma} \\
22\end{array}$} \\
\hline \multirow{5}{*}{$\begin{array}{l}\text { Divergen } \\
\quad\left(\mathrm{B}_{1}\right)\end{array}$} & $\mathrm{n}$ & & & \\
\hline & $\bar{X}$ & 29,82 & 20,82 & 25,32 \\
\hline & $\mathrm{s}$ & 2,71 & 4,02 & 5,69 \\
\hline & Mo & 30,00 & 24,00 & 26,00 \\
\hline & $\mathrm{Me}$ & 30,00 & 24,00 & 26,00 \\
\hline \multirow{5}{*}{$\begin{array}{c}\text { Konvergen } \\
\left(\mathbf{B}_{2}\right)\end{array}$} & $\mathrm{n}$ & 11 & 11 & 22 \\
\hline & $\bar{X}$ & 20,91 & 24,36 & 22,64 \\
\hline & $\mathrm{s}$ & 2,55 & 4,46 & 3,96 \\
\hline & Mo & 20,00 & 18,00 & 20,00 \\
\hline & $\mathrm{Me}$ & 20,00 & 24,00 & 22,00 \\
\hline \multirow{5}{*}{$\mathbf{\Sigma}$} & $\mathrm{n}$ & 22 & 22 & 44 \\
\hline & $\bar{X}$ & 25,36 & 22,59 & 23,98 \\
\hline & $\mathrm{s}$ & 5,23 & 4,52 & 5,03 \\
\hline & Mo & 20,00 & 24,00 & 24,00 \\
\hline & $\mathrm{Me}$ & 20,00 & 24,00 & 24,00 \\
\hline
\end{tabular}

Selanjutnya dilakukan uji normalitas data sebagai persyaratan untuk ujia Anava. Hasil uji normalitas data dipaparkan pada tabel berikut:

Tabel 4 Hasil Uji Normalitas Data

\begin{tabular}{ccccc}
\hline Kelompok & $\mathbf{n}$ & $\mathbf{L}_{\text {hitung }}$ & $\mathbf{L}_{\text {tabel }}$ & Keterangan \\
\hline $\mathrm{A}_{1}$ & 22 & 0,120 & 0,173 & Normal \\
$\mathrm{A}_{2}$ & 22 & 0,163 & 0,173 & Normal \\
$\mathrm{B}_{1}$ & 22 & 0,128 & 0,173 & Normal \\
$\mathrm{B}_{2}$ & 22 & 0,156 & 0,173 & Normal \\
$\mathrm{A}_{1} \mathrm{~B}_{1}$ & 11 & 0,150 & 0,249 & Normal \\
$\mathrm{A}_{1} \mathrm{~B}_{2}$ & 11 & 0,185 & 0,249 & Normal \\
$\mathrm{A}_{2} \mathrm{~B}_{1}$ & 11 & 0,213 & 0,249 & Normal \\
$\mathrm{A}_{2} \mathrm{~B}_{2}$ & 11 & 0,109 & 0,249 & Normal \\
\hline
\end{tabular}

Berdasarkan tabel 4 di atas, terlihat bahwa kedelapan kelompok data hasil penelitian berdistribusi normal sehingga bisa dilanjutkan pada uji Anava.

Hasil uji Anava untuk menjawab hipotesis tersebut dipaparkan pada tabel rangkuman uji Anava berikut ini;

Tabel 5. Hasil Rangkuman Uji ANAVA

\begin{tabular}{cccccc}
\hline $\begin{array}{c}\text { Sumber } \\
\text { Varians }\end{array}$ & JK & db & RJK & Fo & Ftab \\
\hline Antar A & 84,568 & 1 & 84,568 & 6,783 & 4,085 \\
Antar B & 79,114 & 1 & 79,114 & 6,345 & 4,085 \\
Interaksi & 426,568 & 1 & 426,568 & 34,213 & 4,085 \\
Dalam & 498,727 & 40 & 12,468 & & \\
Total & 1088,97 & 43 & & & \\
\hline
\end{tabular}

Berdasarkan hasil uji hipotesis yang dilakukan, terdapat interaksi antara model pembelajaran dengan gaya berpikir. Oleh karena itu untuk membuktikan signifikansi interaksi antar variabel penelitian maka dilakukan pengujian selanjutnya. Dalam hal ini peneliti menggunakan uji t-dunnet dengan taraf signifikansi $\alpha=0,05$. Hasil uji t-dunnet sebagai berikut: 
Tabel 6. Rangkuman Uji Lanjut dengan t-dunnet

\begin{tabular}{cccc}
\hline Kelompok & t o & $\mathbf{t}$ tab & Keterangan \\
\hline A1B1 \& A2B1 & 5,978 & 1,684 & signifikan \\
A1B2 \& A2B2 & 2,294 & 1,684 & signifikan \\
A1B1 \& A1B2 & 5,917 & 1,684 & signifikan \\
A2B1 \& A2B2 & 2,355 & 1,684 & signifikan \\
\hline
\end{tabular}

\section{Pembahasan}

Pembahasan dikelompokkan sesuai dengan jumlah rumusan masalah yang ada. Secara berurutan pembahasan hasil penelitian dideskeipsikan sebagai berikut:

Pertama; perbedaan hasil belajar Filsafat Pendidikan antara mahasiswa yang menggunakan model pembelajaran deep learning dan mahasiwa yang menggunakan model pembelajaran surface learning. Hipotesis statistik yang diuji untuk mengetahui perbedaan adalah sebagai berikut:

$$
\begin{aligned}
& \mathrm{H}_{0}: \mu \mathrm{A} 1 \leq \mu \mathrm{A} 2 \\
& \mathrm{H}_{1}: \mu \mathrm{A} 1>\mu \mathrm{A} 2
\end{aligned}
$$

Hasil analisis menunjukkan bahwa ratarata nilai untuk mahasiswa yang menggunakan model pembelajaran deep learning adalah 25,36 dan nilai rata-rata untuk mahasiswa yang menggunakan model pembelajaran surface learning sebesar 22,59. Hasil uji Anava untuk model pembelajaran adalah $\mathrm{F}_{\text {hitung }}=6,783$ dan $\mathrm{F}_{\text {tabel }}=4,085$, dengan $\mathrm{dk}=1,40$ dimana taraf signifikansi sebesar $\alpha=0,05$. Hasil uji ini menunjukkan bahwa $F_{\text {hitung }}=6,783>F_{\text {tabel }}=$ 4,085, dengan demikian $\mathrm{H}_{1}$ diterima dan $\mathrm{H}_{0}$ ditolak. Hasil penelitian ini sejalan dengan penelitian yang dilakukan oleh Borredon dkk (2011) yang menyatakan bahwa

With all the difficulties, challenges, resistance, and diversity described here, deep learning occurred; that is, students learned something infinitely more challenging and distinctive than acquiring technical skill, passing an examination, or gaining in competition over another.

\section{Bahwa model pembelajaran deep learning} dalam pelaksanaannya menemui berbagai macam kendala, namun saat pembelajaran dengan model deep learning terjadi siswa belajar sesuatu yang jauh lebih menantang dan berbeda, memperoleh keterampilan teknis, lulus ujian, atau berusaha untuk mendapatkan nilai yang lebih baik dari yang lain.

Hasil penelitian ini sejalan dengan penelitian yang dilakukan oleh Chotitham dkk (2013), dalam artikelnya dinyatakan bahwa;

The results showed that Chulalongkorn University students as a whole had high level of deep learning and a path analysis showed that deep learning had positive effects on achievement.

Penelitian oleh Chotitham dkk membuktikan bahwa penerapan model pembelajaran deep learning memberikan dampak positif dalam pencapaian hasil belajar pada mahasiswa Universitas Chulalongkorn.

Berdasarkan kajian yang sudah dikemukakan pada bagian pendahuluan bahwa model pembelajaran deep learning adalah model pembelajaran yang memungkinkan mahasiwa untuk mengeksplorasi semua kemampuan berpikirnya, karena dalam mobel pembelajaran deep learning terhadap tahapan-tahapan yang menuntun mahasiswa untuk menggunakan semua kemampuan berpikir yang dimilikinya.

Kedua; pengaruh interaksi antara model pembelajaran dengan gaya berpikir terhadap hasil belajar Filsafat Pendidikan. Hipotesis yang 
diajukan untuk rumusan masalah pada kelompok pembahasan ini adalah;

$$
\begin{aligned}
& \mathrm{H}_{0}: \text { Int. } \mathrm{AXB}=0 \\
& \mathrm{H}_{1} \text { : Int. } \mathrm{AXB} \neq 0
\end{aligned}
$$

Berdasarkan nilai mata kuliah Filsafat Pendidikan diperoleh nilai rata-rata untuk deep learning dengan gaya berpikir divergen sebesar 28,89, deep learning dengan gaya berpikir konvergen sebesar 20,91, surface learning dengan gaya berpikir divergen sebesar 20,82 dan surface learning dengan gaya berpikir konvergen sebesar 34,36. Hasil uji hipotesis pada $\mathrm{dk}=1,40$ dan taraf signifikansi $\alpha=0,05$ diperoleh hasil $F_{\text {hitung }}=34,213$ dan $F_{\text {tabel }}=4,085$. Hasil uji ini menunjukkan bahwa $\mathrm{F}_{\text {hitung }}=34,213>\mathrm{F}_{\text {tabel }}=$ 4,085, dengan demikian $\mathrm{H}_{0}$ ditolak dan dapat dibuktikan terdapat interaksi antara model pembelajaran dan gaya berpikir terhadap hasil belajar mahasiswa pada Mata Kuliah Filsafat Pendidikan.

Gaya berpikir memiliki potensi untuk meningkatkan efektifitas dan efisiensi model pembelajaran yang digunakan oleh mahasiswa, sebagaimana dikemukakan oleh Riding dan Smith (1997) bahwa

the accommodation of cognitive style in the training design process has the potential to improve the efficiency and effectiveness of individual learning and may also help the identification of learning difficulties.

Mahasiswa dengan gaya berpikir divergen relatif mudah dalam mempelajari sesuatu karena mahasiswa yang memiliki gaya berpikir divergen lebih dinamis dan terbuka dalam belajar. Cenderung dapat menyelesaikan berbagai macam problem dengan satu pendekatan. Di sisi lain deep learning menitik beratkan kegiatan belajar pada proses memeriksa fakta dan ide baru secara kritis, dan mengikat mereka ke dalam struktur kognitif yang ada dan membuat banyak tautan antar ide. Dengan demikian model pembelajaran deep learning membuka simpul-simpul kognitif yang baru dan mengaitkan fakta, konsep dan ide baru dalam disiplin Filsafat Pendidikan.

Demikian pula halnya pada mahasiswa yang memiliki gaya belajar konvergen, dimana gaya belajar berkaitan dengan kemampuan memproduksi satu jawaban benar. Selain itu gaya berpikir konvergen mendorong mahasiswa untuk menyelesaikan berbagai situasi dan masalah dengan solusi yang parsial, cenderung tertutup dan statis, gaya berpikir konvergen bisa menyelesaikan masalah dengan sangat baik dan hati-hati tapi tuntas. Model pembelajaran surface learning relevan dengan gaya berpikir konvergen, karena pada surface learning mahasiswa belajar hanya karena ingin lulus saja, tidak merefleksikan tujuan atau strategi. Dalam hal ini pembelajaran hanya sebatas proses belajar sebagai bagian dari pengetahuan yang tidak terkait, dan menghafal fakta serta. Kreatifitas tidak bisa berkembang dalam mobel pembelajaran surface learning dan hal ini sesuai dengan gaya berpikir konvergen.

Interaksi antara gaya berpikir konvergen dan model pembelajaran surface learning signifikan pada hasil uji untuk hipotesis ini. Irisan yang terjadi antara garis gaya berpikir dan model pembelajaran membuktikan signifikansi tersebut. Dalam penelitian ini siswa yang memiliki gaya berpikir konvergen cenderung menyelesaikan persoalan secara parsial, cenderung hati-hati tetapi tuntas. Hal ini terlihat 
dari grafik interaksi sebagaimana digambarkan di bawah ini.

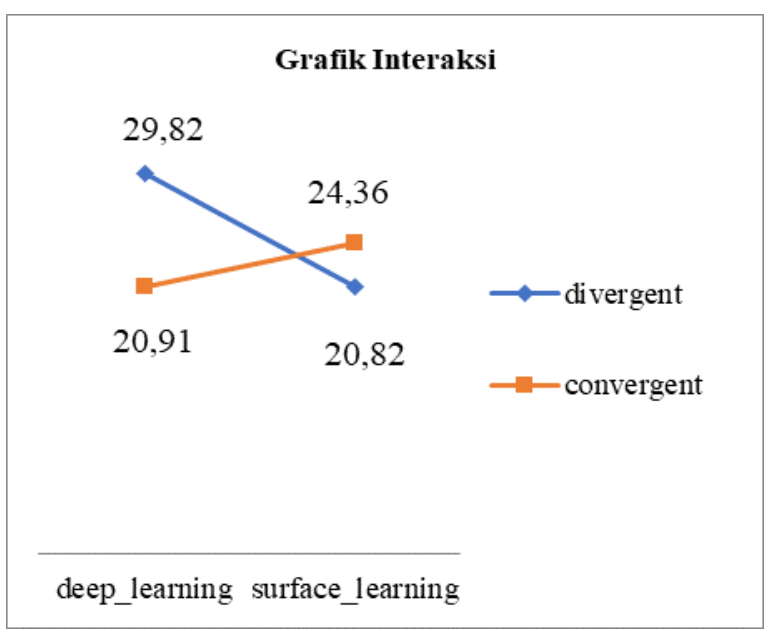

Gambar. 1 Grafik Interaksi Model Pembelajaran dan Gaya Berpikir terhadap Hasil Belajar Filsafat Pendidikan

Berdasarkan hasil uji interaksi telah dibuktikan bahwa $\mathrm{h}_{0}$ ditolak dan $\mathrm{h}_{1}$ diterima. Selanjutnya dilakukan uji lanjut menggunakan uji t-Dunnet. Hasil uji Dunnet dipaparkan sebagai berikut:

Tabel 7. Signifikansi antar kelompok penelitian

\begin{tabular}{|c|c|c|c|}
\hline Kelompok & $\mathbf{T}_{\text {hit }}$ & $\mathbf{t}_{\text {tab }}$ & Keterangan \\
\hline A1B1 \& A2B1 & 5,978 & 1,684 & signifikan \\
\hline A1B2 \& A2B2 & 2,294 & 1,684 & signifikan \\
\hline A1B1 \& A1B2 & 5,917 & 1,684 & signifikan \\
\hline A2B1 \& A2B2 & 2,355 & 1,684 & signifikan \\
\hline
\end{tabular}

Berdasarkan tabel 7 di atas jelas menunjukkan bahwa interaksi yang ditunjukkan oleh dalam gambar 1 bahwa interaksi antara model pembelajaran dan gaya berpikir signifikan. Hal ini disebabkan oleh model pembelajaran deep learning merupakan model pembelajaran yang relevan dengan mata kuliah Filsafat Pendidikan yang membutuhkan kemampuan berpikir yang mendalam dan komprehensif sejalan dengan hasil penelitian yang dilakukan oleh Chotitham dkk yang menyatakan bahwa

Result showed that Chulalongkorn University students as a whole had high level of deep learning and a path analysis showed that deep learning had positive effects on achievement.

Ketiga; perbedaan hasil belajar mahasiswa yang menggunakan metode pembelajaran deep learning dan metode pembelajaran surface learning dan memiliki gaya berpikir divergen. Hipotesis yang diajukan adalah

$$
\text { Ho: } \mu \mathrm{A} 1 \mathrm{~B} 1 \leq \mu \mathrm{A} 2 \mathrm{~B} 1
$$$$
\text { H1: } \mu \mathrm{A} 1 \mathrm{~B} 1>\mu \mathrm{A} 2 \mathrm{~B} 1
$$

Berdasarkan hasil perhitungan uji t yang dikembangkan Dunnett diperoleh harga harga $\mathrm{t}_{\text {hitung }}=5,917$ sedangkan $\mathrm{t}_{\text {tabel }}=1,684$. Berdasarkan hasil perhitungan ini $t_{\text {hitung }}$ lebih besar dari pada $t_{\text {tabel }}(5,917>1,684)$. Dengan demikian terdapat perbedaan yang signifikan antara kedua kelompok siswa yang memiliki gaya berpikir konvergen dengan menggunakan model pembelajaran deep learning dan surface learning. Model pembelajaran deep learning adalah model pembelajaran yang dinamis namun rigid. Model pembelajaran ini memungkinkan mahasiswa untuk mendalami materi-materi pada mata kuliah Filsafat Pendidikan secara konfrehensif, dan memahami makna dibalik setiap konsep, teori dan preposisi yang ada di dalam materi. Mahasiswa yang memiliki gaya berpikir divergen dengan mudah dapat mengikuti langkah dan tahapan-tahapan dalam model pembelajaran deep learning, bila dibandingkan dengan mahasiswa yang belajar dengan model pembelajaran surface learning. Dikatahu bahwa 
pada model pembelajaran surface learning, mahasiswa belajar hanya untuk lulus tanpa ada keinginan dan minat untuk mendalami materi yang diikuti, prinsipnya adalah yang penting lulus.

Keempat; Perbedaan hasil belajar mahasiswa yang menggunakan model pembelajaran deep learning dan surface learning dan model memiliki gaya berpikir konvergen. Hipotesis yang diajukan dalam penelitian adalah sebagai berikut;

Ho: $\mu \mathrm{A} 2 \mathrm{~B} 1 \geq \mu \mathrm{A} 2 \mathrm{~B} 2$

$\mathrm{H} 1: \mu \mathrm{A} 2 \mathrm{~B} 1<\mu \mathrm{A} 2 \mathrm{~B} 2$

Hasil uji t-dunnett untuk menjawab hipotesis ini adalah $t_{\text {hitung }}=2,355$ sedangkan $t_{\text {tabel }}$ $=1,684$. Hasil uji ini menunjukkan bahwa $t_{\text {hitung }}$ $>t_{\text {tabe }}$ atau 2,355 $>1,684$, hasil uji ini juga membuktikan bahwa perbedaan hasil belajar antara kedua kelompok yang memiliki gaya berpikir yang sama-sama konvergen ini dengan model pembelajaran yang berbeda. Dengan demikian $\mathrm{H}_{0}$ ditolak dan $\mathrm{H}_{1}$ diterima.

Signifikansi perbedaan hasil belajar pada dua kelompok mahasiswa dengan gaya berpikir konvergen tapi diberi perlakuan dengan dua model pembelajaran yang berbeda cukup beralasan, dimana hasil belajar mahasiswa yang memiliki gaya berpikir konvergen dan menggunakan model pembelajaran surface learning lebih tinggi dari pada mahasiswa yang menggunakan model pembelajaran deep learning. Telah diuraikan sebelumnya bahwa gaya berpikir konvergen cenderung menyelesaikan permasalahan secara parsial dalam arti bahwa setiap satu solusi hanya untuk satu permasalahan. Hal ini relevan dengan model pembelajaran surface learning yang statis dan dipengaruhi oleh motivasi ekstrinsik. Dengan demikian bagi mahasiswa yang memiliki gaya berpikir konvergen, akan lebih efektif jika menggunakan model pembelajaran surface learning dalam pembelajaran khususnya dalam pembelajaran mata kuliah Filsafata Pendidika.

\section{KESIMPULAN}

Berdasarkan hasil uji hipotesis dan pembahasan hasil uji atau hasil penelitian sebagaimana telah diuraikan di atas, maka kesimpulan dalam penelitian ini dikemukakan sebagai berikut:

Pertama: Hasil belajar filsafat Pendidikan mahasiswa yang menggunakan model pembelajaran deep learning lebih tinggi dibanding kelompok mahasiswa yang menggunakan model pembelajaran surface learning. Dengan demikian model pembelajaran deep learning efektif untuk meningkatkan hasil belajar filsafat Pendidikan.

Kedua: Untuk kelompok mahasiswa yang memiliki gaya berpikir divergen, hasil belajar filsafat pendidikan antara kelompok mahasiswa yang menggunakan model pembelajaran deep learning lebih tinggi dibandingkan kelompok mahasiswa yang menggunakan model pembelajaran surface learning. Dengan demikian untuk meningkatkan hasil belajar pada matak uliah filsafat Pendidikan bagi mahasiswa yang memiliki gaya berpikir divergen lebih tepat menggunakan model pembelajaran deep learning.

Ketiga: Terdapat pengaruh interaksi antara model pembelajaran dan gaya berpikir terhadap hasil belajar filsafat pendidikan. Dengan demikian, hasil belajar filsafat Pendidikan pada 
mahasiswa yang menggunakan model pembelajaran deep learning dan mempunyai gaya berpikir divergen berbeda dengan hasil belajar mahasiswa yang menggunakan model pembelajaran surface learning dan memiliki gaya berpikir konvergen. Oleh karena itu dalam melakukan penilaian hasil belajar mahasiswa dapat mempertimbangkan karakteristik perbedaan individu dengan mahasiswa yang mempunyai gaya berpikir konvergen.

Keempat: Untuk kelompok mahasiswa yang memiliki gaya berpikir konvergen dan menggunakan model pembelajaran deep learning, hasil belajar filsafat pendidikan lebih rendah dibandingkan mahasiswa yang memiliki gaya berpikir konvergen dan menggunakan model pembelajaran surface learning. Dengan demikian model pembelajaran surface learning lebih tepat jika diterapkan pada siswa yang memiliki gaya berpikir konvergen.

Penelitian ini perlu dilanjutkan dengan penelitian-penelitian yang sejenis, baik dalam disiplin ilmu yang sama bahkan juga dalam disiplin ilmu yang berbeda. Mengingat model pembelajaran deep learning lebih dominan digunakan dalam penelitian bidang eksakta, maka diharapkan penelitia-penelitian lanjutan dapat dilakukan dalam disiplin ilmu non-eksakta.

\section{DAFTAR PUSTAKA}

Anas Salahudin, Filsafat Pendidikan,: Pustaka Setia; Bandung, 2011, cet. ke-10, hlm. 22-23.

Badgett, J. L., Christmann, E. P. Designing Elementary Instruction and Assessment, Corwin: SAGE Company, 1981.

Bim-Bad, Boris Michailovich, and Egorova, Lioudmila Ivanovna., Interaction Between Philosophy of Education and
Teaching Practice. International Journal of Environmental \& Science Education Vol. 11, No. 10., 2016

Chotitham S, Wongwanich Suwimon, and Wiratchai Nonglak. Deep Learning and its Effects on Achievement. ProceedingSocial and Behavioral Sciences 116 (2014) $3313-3316.5^{\text {th }}$ World Conference on Educational Sciences WCES 2013. www.https://core.ac.uk

Conradt, Jorg Deep Learning Neural Networks on Mobile Platforms. Advanced Seminar for Andreas Plieninger, Mat-Nr. 3617584. https://www.nst.ei.tum.de/ fileadmin/w00bqs/www/publications diakses Januari 2018

Dewey, J. Democracy and Education. Indiana; Southern Illinois UP. 1985

Dwirahayu, Gelar dan Firdausi. Pengaruh gaya Berpikir Terhadap Kemampuan Koneksi Matematis Mahasiswa. Jurnal Penelitian dan Pembelajaran Matematika (JPPM), Untirta. Vol. 9 No. 22016.

Gagne, Robert M. The Conditions of Learning. Third Edition. New York: Rinehart and Winston, 1977.

Gredler, Margareth E. Learning in Instruction: Theory in to Practice 6th Edition. Terjemahan Tri Wibowo B.S. Jakarta: Kencana Perdana Media Group, 2011.

Houghton, W. Engineering Subject Centre Guide : Learning and Teaching Theory for Engi neering Academics. Loughborough: HE A. 2004.

Howie, Peter \& Bagnall, Richard Gordon. A Critique of the Deep and Surface Approaches to Learning. Teaching in Higher Education Journal. Volume 18, 2013. Pp 389-400. www.tandfonline.com

Jalaluddin dan Abdullah Idi, Filsafat Pendidikan,: Gaya Media Pratama; Jakarta, 2002 cet. ke-2, hlm. 13.

Jensen, Eric \& LeeAn Nickelsen. Deeper Learning: 7 Powerful Strategies for InDepth and Longer-Lasting Learning 1st Edition. Corwin Press. 2008

Jordan, Chapter 1 Philosophy of education. www.mheducation.co.uk/openup/chapter s/9780335226702.pdf 
Liz Borredon, Sylvie Deffayet, Ann C. Baker, and David Kolb. Enhancing Deep Learning: Lessons from the Introduction of Learning Teams in Management Education in France. Journal of Management Education Vol. 35 No. 3, pp. 324-350, 2011

Muhammad Kristiawan, Filsafat Pendidikan, Valia Pustaka Yogyakarta, 2016.

Pencheva, Eliana S \&. Papazova, Eva B. Cognitive Style and Values. Psychological Type and Culture-East \& West: A Multicultural Research Conference Honolulu, Hawaii, January 6-8, 2006. uploaded by Eva Papazova on 27 September 2015.

Redja Mudyahardjo, Pendidikan Ilmu Pendidikan: Rosda Karya; Bandung, 2004, hlm. 3-4.

Reigeluth, Charles M. Instructional Design, Theories and Models: An Overview of Their Current Status. Hillsdale, New Jersey: Lawrence Erlbaum Associates, Inc., 1983

Riding. J Richard and Eugene Sadler-Smith, Cognitive Style and Learning Strategies:
Some Implications for Training Design. International journal of Training and Development. 1997.

Seifert, Kelvin. Educational Psychology. Boston: Houghton Mifflin Company,1983.

Siegel, Harvey., Introduction: Philosophy of Education and Philosopy, www.researchgate.net/publication/

Slavin, Robert E. Educational Psychology, Theory and Practice 9th Edition. Terjemahan Samosir. Jakarta: PT Indeks, 2011.

Suryana, Model Pembelajaran Efektif. file.upi.edu/Direktori/FPEB/PRODI. MNAJEMEN_FPEB/.../FILE_16.pdf

Uto, M. On some questions in connection with cognitive styles. Bulgarian journal of psychology. Vol. 4, pp. 3-19. 1994

Moore, T.W., Philosophy of Education: An Introduction. Routledge \& Kegan Paul. London, Boston, Melbourne and Henley. 2010. http://www.sjposd.com/PDF/ PHILOSOPHY\%20OF\%20EDUCATIO N.pdf 